\title{
PENINGKATAN MOTIVASI, KEMANDIRIAN DAN HASIL BELAJAR MELALUI PEMBELAJARAN KOOPERATIF PADA PEMBELAJARAN DASAR SINYAL AUDIO
}

\author{
Santi Utami \\ SMKN 1 Saptosari Gunungkidul \\ san_unt@yahoo.com \\ Soenarto \\ Universitas Negeri Yogyakarta \\ soenarto@uny.ac.id
}

\begin{abstract}
Abstrak
Penelitian ini bertujuan untuk meningkatkan motivasi belajar, kemandirian dan hasil belajar siswa melalui strategi pembelajaran kooperatif tipe Student Teams Achievement Division (STAD) di SMKN 1 Saptosari. Penelitian ini merupakan Penelitian Tindakan Kelas (PTK) dengan empat tahapan yaitu perencanaan, pelaksanaan, pengamatan dan refleksi. Penelitian di SMKN 1 Saptosari dengan subyek penelitian siswa kelas X Teknik Audio Video A. Penelitian melibatkan seorang kolaborator yang berasal dari teman sejawat. Teknik pengumpulan data menggunakan dokumentasi, lembar observasi kelas dan lembar ceklist. Data penelitian yang menunjukkan adanya perubahan dari tindakan yang diberikan diperoleh dari kolaborator. Data yang diperoleh dianalisis dengan statistik deskriptif. Hasil penelitian menunjukkan bahwa: (1) melalui strategi pembelajaran kooperatif tipe STAD sebanyak 76,6\% siswa meningkat motivasinya, (2) melalui strategi pembelajaran kooperatif tipe STAD sebanyak 69\% siswa meningkat kemandiriannya, dan (3) pembelajaran kooperatif tipe STAD mampu meningkatkan hasil belajar siswa hingga memenuhi Kriteria Ketuntasan Minimal (KKM).
\end{abstract}

Kata kunci: motivasi, kemandirian, hasil belajar, pembelajaran kooperatif

\section{IMPROVING STUDENT'S MOTIVATION, AUTONOMY AND LEARNING OUTCOMES THROUGH THE COOPERATIVE LEARNING IN THE LEARNING OF BASIC AUDIO SIGNAL}

\begin{abstract}
This study aims to improve student's learning motivation, autonomy, and learning outcomes through the cooperative learning strategy of the Student Teams Achievement Division (STAD) type at SMKN 1 Saptosari. This was a classroom action research (CAR) study consisting of four stages, i.e. planning, action, observation, and reflection. It was conducted in SMKN 1 Saptosari and the research subjects were Grade X students of Audio Video Engineering A. It involved a collaborator who was a colleague. The data collecting techniques were documentation, a classroom observation sheet, and a checklist. The research data showing changes as a result of the actions were obtained from the collaborator. The data were analyzed by means of the descriptive technique. The results of the study showed that: (1) through the cooperative learning of the STAD type was capable of improving the motivation of $76.6 \%$ of the students, (2) the cooperative learning of the STAD type was capable of improving the autonomy of $69 \%$ of the students, and (3) the cooperative learning of the STAD type was capable of improving the students'learning outcomes to satisfy the Minimum Mastery Criterion (MMC).
\end{abstract}

Keywords: motivation, autonomy, learning outcomes, cooperative learning 


\section{PENDAHULUAN}

Pendidikan merupakan cerminan kemajuan suatu bangsa. Semakin tinggi budaya suatu bangsa, semakin tinggi pula tingkat pendidikan bangsa tersebut. Bangsa yang besar adalah bangsa yang memperhatikan pendidikan warga negaranya. Menurut UU Sisdiknas No.20 tahun 2003 pendidikan adalah usaha sadar dan terencana untuk mewujudkan suasana belajar dan proses pembelajaran agar peserta didik secara aktif mengembangkan potensi dirinya untuk memiliki kekuatan spiritual keagamaan, pengendalian diri, kepribadian, kecerdasan, akhlak mulia serta ketrampilan yang diperlukan dirinya, masyarakat, bangsa dan negara.

Dalam UU Sisdiknas No.20 Tahun 2003 pasal 14 dan diperinci lagi pada pasal 18 ayat 3 yang berbunyi "Pendidikan Menengah berbentuk Sekolah Menengah Atas (SMA), Madrasah Aliyah (MA), Sekolah Menengah Kejuruan (SMK) dan Madrasah Aliyah Kejuruan (MAK), atau bentuk lain sederajat". SMK adalah sekolah yang membekali anak didiknya dengan berbagai macam ketrampilan sesuai program keahliannya. Dengan lulusan yang terampil/siap kerja, tentunya SMK adalah solusi bagi masalah pengangguran di Indonesia yang jumlahnya terus meningkat (MJeducation.com). Prinsip pendidikan kejuruan menurut Prosser dalam bukunya yang berjudul "Vocational Education in a democracy" point $1 \& 2$ yang dikutip oleh Djojonegoro, (1998, p.38) dikatakan bahwa : (1) pendidikan kejuruan akan efisien apabila disediakan lingkungan belajar yang sesuai dengan-semisal replika dari lingkungan dimana mereka kelak akan bekerja dan (2) latihan kejuruan yang efektif hanya dapat diberikan jika tugas-tugas yang diberikan di dalam latihan memilki kesamaan operasional, dengan peralatan yang sama dan dengan mesin-mesin yang sama dengan yang akan digunakan di dalam kerjanya kelak.

Dari paparan di atas berarti pendidikan kejuruan dikatakan efektif dan efisien bila lingkungan belajar sama dengan lingkungan kerja kelak, pembelajaran dilakukan langsung dengan penugasan yang diberikan memiliki operasional yang sama dengan yang akan digunakan di lingkungan kerjanya kelak.
Namun kenyataan di lapangan menunjukkan hal berbeda. Dari survei yang dilakukan di beberapa SMK di Gunungkidul menunjukkan bahwa lingkungan sekolah belum mendukung proses pembelajaran, kurang komunikatifnya guru dan letak geografis daerah tempat tinggal siswa yang jauh dari akses pendidikan. Hal ini mempengaruhi motivasi belajar siswa.

SMKN 1 Saptosari adalah salah satu SMK di Gunungkidul yang memiliki beberapa permasalahan antara lain ketidakjujuran siswa yang terlihat pada saat ulangan, perilaku siswa di kelas yang cenderung bermalas-malasan dan tidak memperhatikan apa yang disampaikan guru serta hasil belajar yang belum memenuhi Kriteria Ketuntasan Minimal (KKM). Hal ini merupakan permasalahan kelas yang harus segera diselesaikan. Salah satu cara yang ditempuh untuk menyelesaikan masalah ini adalah penggunaan strategi pembelajaran kooperatif.

\section{Pembelajaran Kooperatif}

Menurut Slavin $(2005$, p.1) pembelajaran kooperatif dapat diaplikasikan untuk semua kelas, yaitu : kelas khusus untuk anak berbakat, kelas pendidikan khusus, kelas dengan kecerdasan rata-rata dan sangat diperlukan dalam kelas heterogen dengan berbagai tingkat kemampuan. Pembelajaran kooperatif juga mampu menumbuhkan motivasi dalam diri siswa seperti yang diungkapkan Slavin (2005, p.34) bahwa "dari perspektif motivasional struktur tujuan kooperatif menciptakan sebuah situasi dimana satu-satunya cara anggota kelompok bisa meraih tujuan pribadi mereka adalah jika kelompok mereka sukses". Menurut Killen (2009, pp.211-212) pembelajaran kooperatif adalah strategi mengajar yang paling banyak diteliti terutama dari segi kemanfaatan dan keefektifan. Di dalam pembelajaran kooperatif terjalin kerjasama untuk mencapai tujuan bersama. Menurut Dell (2007, p.317) pembelajaran kooperatif adalah pendekatan pembelajaran yang menyediakan kesempatan dan pengelolaan kelompok belajar. Sedangkan menurut Strommen (1995, p.24) strategi pembelajaran kooperatif melibatkan kelompok-kelompok kecil yang dalam satu kelompok terdiri dari siswa dengan prestasi tinggi, sedang dan rendah. Borich (2007, 
p.371) berpendapat bahwa pembelajaran kooperatif mampu menumbuhkan kemandirian siswa dalam proses pembelajaran. Slavin (1988, p.31) menyatakan bahwa pembelajaran kooperatif sebagai alternatif untuk kemampuan kelompok khususnya menumbuhkan bakat siswa. Roger (1994,p.1) menyatakan bahwa dalam pembelajaran kooperatif terjadi interaksi yang positif. Slavin (2005,p.1) menyatakan bahwa pembelajaran kooperatif dapat diaplikasikan untuk semua kelas dan dapat menunmbuhkan motivasi dari dalam diri siswa. Pembelajaran kooperatif memiliki lima jenis yaitu: (1) Students Team Achievement Division/STAD, (2) Team Game Tournament/ TGT, (3) Jigsaw II, (4) Team Accelerated Instruction/TAI, (5) Cooperative Integrated Reading and Composition/CIRC.

Ide utama pembelajaran metode STAD adalah untuk memotivasi siswa agar saling membantu dalam memahami sebuah materi pelajaran dan saling membantu dalam menyelesaikan masalah. Agar mendapatkan penghargaan dari guru maka tim mereka harus mempunyai nilai tinggi dalam evaluasi yang diberikan. Oleh karena itu kerjasama tim dan saling memotivasi akan mengantarkan mereka pada kesuksesan. Lima komponen pembelajaran kooperatif tipe STAD menurut Slavin adalah: (1) presentasi kelas, (2) kerja tim, (3) kuis, (4) penghargaan individu dan (5) penghargaan kelompok.

\section{Motivasi Belajar}

Menurut Hamalik (2002, p.173) motivasi adalah perubahan energy didalam pribadi seseorang yang ditunjukkan dengan timbulnya afektif dan reaksi untuk mencapai tujuan. Menurut Schunk (2010, p.8) " Motivation is the process whereby goal directed activity is instigated and sustained" yang berarti bahwa motivasi adalah proses dengan mengarahkan tujuan yang berkelanjutan. Adapun motivasi menurut Kidd (2010, p.190) berpendapat bahwa "Motivation refers to what triggers an individual to do something, and to want to do it" yang berarti bahwa motivasi mengacu pada dorongan seseorang untuk melakukan sesuatu dan keinginan untuk melakukannya. Motivation is the reason or cause that produce some effect (Chance, 2009, p.128). Capel
(1997, p.95) berpendapat bahwa motivasi bisa bersifat intrinsik (motivasi dari diri sendiri lebih dalam dibandingkan dengan orang lain, seperti kemampuan berprestasi dalam memecahkan sebuah pekerjaan yang sulit) dan ekstrinsik (motivasi dari orang lain seperti harapan guru untuk pekerjaan yang bagus). Para siswa dapat termotivasi oleh beberapa factor, antara lain: (a) prestasi, (b) kesenangan, (c) mencegah atau menghentikan kegiatan yang tidak bermakna, (d) kepuasan, (e) kesuksesan. Seorang siswa yang tidak termotivasi mungkin tidak mendengarkan apa yang guru katakan, bicara sendiri, terlihat bosan atau melihat jauh ke jendela. Motivasi yang rendah dihasilkan dari beberapa faktor antara lain kebosanan atau tugas yang dirasa terlalu sulit. Menurut Djaali (2008, p.101) berpendapat bahwa " motivasi adalah kondisi fisiologis dan psikologis yang terdapat dalam diri seseorang yang mendorongnya untuk melakukan aktivitas tertentu guna mencapai suatu tujuan (kebutuhan)'. Menurut Alderman (2004, p.23). motivasi mempunyai tiga fungsi yaitu : (a) mengaktifkan tingkah laku atau sikap, (b) mengarahkan sikap atau tingkah laku, dan (c) mengarahkan tingkah laku secara berkelanjutan. Adapun motivasi belajar menurut Uno (2011, p.23) adalah dorongan internal dan eksternal pada siswa yang sedang belajar untuk mengadakan perubahan tingkah laku pada umumnya dengan beberapa indikator atau unsur yang mendukung. Indikator motivasi belajar dapat diklasifikasikan sebagai berikut: (1) adanya hasrat dan keinginan berhasil; (2) adanya dorongan dan kebutuhan dalam belajar; (3) adanya harapan dan cita-cita masa depan; (4) adanya penghargaan dalam belajar; (5) adanya kegiatan yang menarik dalam belajar dan (6) adanya lingkungan belajar yang kondusif, sehingga siswa dapat belajar dengan baik. Motivasi dapat berupa motivasi intrinsik dan mtivasi ekstrinsik. Menurut Reid (2009, p.27) motivasi intrinsik adalah hasrat untuk memulai tugas yang berkar dari dalam individu. Weil (1996, p.27) berpendapat bahwa motivasi intrinsik berasal dari dalam diri seseorang yang tidak dipengaruhi oleh kondisi di luar dirinya. Sedangkan motivasi ekstrinsik menurut Weil (1996, p.28) motivasi yang berasal dari pengaruh luar misalnya 
hukuman dan penghargaan. Capel (1997, p.101) berpendapat " Factors influencing motivation to learn are: (a) success, (b) praise, (c) punishment, (d) feedback". Factor-faktor yang mempengaruhi motivasi belajar adalah: (a) sukses, (b) penghargaan, (c) hukuman dan (d) umpan balik.

\section{Kemandirian}

Menurut Ali (2008, p.114), kemandirian merupakan suatu kekuatan internal individu yang diperoleh melalui proses individuasi. Monks (1994, p.279) mengatakan bahwa orang yang mandiri akan memperlihatkan perilaku yang eksploratif, mampu mengambil keputusan, percaya diri dan kreatif. McLean (2009, p.44) menyatakan bahwa siswa-siswa mempunyai tingkah laku yang mempengaruhi bagaimana cara mereka belajar dan tingkah laku ini menggambarkan tingkat kemandirian mereka. Sebagai contoh mungkin mereka melihat aktivitas kelas sebagai tes atau alat ukur dari kemampuan mereka atau sebagai peluang belajar. Tingkah laku ini merefleksikan dua kemampuan motivasi : kebutuhan berprestasi dan kebutuhan untuk mencegah kegagalan. Perilaku berprestasi diarahkan untuk mengembangkan dan menujukkan kemampuan yang dimiliki. Menurut Smith (2012, p.396) kemandirian belajar adalah keinginan dan kemampuan untuk bergerak secara mandiri dan mampu bekerjasama dengan orang lain dan bertanggung jawab. Ringer (1990, pp.3536) berpendapat bahwa "Seseorang yang dikatakan mandiri apabila: (1) dapat bekerja sendiri secara fisik, (2) dapat berfikir sendiri atau berpindah dari suatu tingkatan abstraksi ke abstraksi berikutnya secara mental, (3) dapat menyusun serta mengekspresikan gagasan dan cara mengekspresikan dapat dimengerti orang lain, dan (4) kegiatan yang dilakukan diabsahkan oleh diri sendiri secara emosional". Ali (2008, p.117) menjelaskan bahwa dari hasil penelitian pada umumnya menunjukan bahwa tingkat kemandirian pada remaja menyebar pada tingkatan sadar diri, seksama, individualistis, dan mandiri. Menuru Thoha (1996, pp.124-125) faktor-faktor yang mempengaruhi kemandirian dapat dibedakan dari dua arah, yakni (1) faktor dari dalam yang berasal dari anak antara lain faktor kematangan usia dan jenis kelamin, disamping itu intelegensi anak juga berpengaruh terhadap kemandirian anak, dan (2) faktor dari luar, antara lain adalah: (a) kebudayaan, masyarakat yang maju dan kompleks tuntutan hidupnya cenderung mendorong tumbuhnya kemandirian dibanding dengan masyarakat yang sederhana; (b) keluarga, meliputi aktifitas pendidikan dalam keluarga,kecendrungan cara mendidik anak, cara memberikan penilaian kepada anak bahkan sampai cara hidup orang tua berpengaruh terhadap kemandirian anak dan (c) sistem pendidikan di sekolah. Proses pendidikan di sekolah yang tidak mengembangkan demokrasi pendidikan dan cenderung menekankan indoktrinasi tanpa argumentasi akan menghambat perkembangan kemandirian remaja sebagai siswa; (4) sistem kehidupan di masyarakat. Sistem kehidupan masyarakat yang terlalu menekankan pentingnya hirarki struktur sosial, merasa kurang aman atau mencekam serta kurang menghargai manifestasi potensi remaja dalam kegiatan produktif dapat menghambat kelancaran perkembangan kemandirian remaja atau siswa.

\section{Hasil Belajar}

Suprijono (2010, p.3) mendefinisikan belajar sebagai kegiatan psiko-fisik-sosio untuk menuju perkembangan pribadi selanjutnya. Sanjaya (2007, p.112) berpendapat bahwa belajar merupakan perubahan tingkah laku akibat pengalaman dan lingkungan. Proses perubahan tingkah laku seseorang tidak dapat disaksikan tetapi bisa dilihat dari gejala-gejala perubahan yang tampak. Sudjana (2009, p.111) berpendapat bahwa hasil belajar adalah kemampuan yang dimiliki siswa setelah ia menerima pengalaman belajarnya. Menurut Jenkins dalam Uno (2011, p.17) hasil belajar adalah pernyataan yang menunjukkan tentang apa yang mungkin dikerjakan siswa sebagai hasil dari kegiatan belajarnya. Rasyid (2008, p.9) berpendapat bahwa jika di tinjau dari segi proses pengukurannya, kemampuan seseorang dapat dinyatakan dengan angka. Kemampuan siswa dalam belajar dapat dilihat dari aspek kognitif, afektif dan psikomotorik. Bloom (1956, p.7) mengungkapkan bahwa "Our original plans called for a complete taxonomy 
in three major parts- the cognitive, the affective and the psychomotor domains". Pada awalnya taxonomi terdiri dari tiga ranah yaitu kognitif, afektif dan psikomotorik. Ranah kognitif terdiri dari beberapa tingkatan yaitu: (1) pengetahuan, (2) pemahaman, (3) penerapan, (4) analisa, (5) sintesa dan (6) evaluasi.

\section{METODE PENELITIAN}

Penelitian ini merupakan Penelitian Tindakan Kelas (Classroom Action Research). Penelitian Tindakan Kelas bertujuan untuk meningkatkan kualitas proses dan hasil pendidikan dengan memberikan perlakuan tertentu kepada siswa. Sebelum penelitian dilaksanakan, terlebih dahulu melakukan dilakukan observasi kelas untuk mengetahui kondisi kelas, interaksi antara guru dengan siswa, serta mencari berbagai permasalahan selama proses pembelajaran berlangsung. Selanjutnya dicari akar penyebab permasalahan dan rencana penyelesaian yang akan menjadi acuan awal penelitian.

Pengamatan terhadap obyek dilakukan oleh kolaborator dan peneliti setiap kali pembelajaran menggunakan lembar observasi berupa check list untuk mengukur perilaku siswa. Perilaku guru dan siswa juga diamati oleh observer mengunakan lembar observasi kelas. Hasil belajar siswa diketahui dari hasil tes atau ulangan harian di setiap kompetensi dasar kemudian dianalisis. Lembar observasi kelas diisi oleh observer dengan menuliskan tanda $\checkmark$ pada kolom waktu dimana sebuah aktivitas sedang berjalan dalam rentang waktu tersebut. Lembar observasi motivasi dan kemandirian siswa juga diisi dengan menuliskan tanda $\checkmark$ pada kolom yang disediakan. Lembar observasi ini menggunakan skala Guttman. Dari lembar observasi ini bisa diketahui tingkat motivasi dan kemandirian siswa dari minggu ke minggu dan diharapkan terjadi peningkatan di tiap minggunya. Setelah terjadi perubahan sikap siswa yaitu motivasi dan kemandirian siswa seperti yang diharapkan maka penelitian ini dihentikan. Peningkatan yang diharapkan adalah sebesar $75 \%$ dari jumlah siswa mengalami peningkatan motivasi dan kemandirian dalam pembelajaran serta rerata kelas sebesar 7,0 sesuai dengan $\mathrm{KKM}$ yang sudah ditentukan.

\section{Lokasi dan Waktu Penelitian}

Penelitian ini dilaksanakan pada bulan Mei sampai dengan Juni 2013 di SMKN 1 Saptosari Gunungkidul. Peneliti mengambil waktu ini karena mata pelajaran Memahami Dasar Sinyal Audio diberikan di semester dua kelas X. Semester dua dimulai dari bulan Januari hingga Juni.

\section{Deskripsi Tempat Penelitian}

Penelitian tindakan kelas ini dilaksanakan di kelas X AV A SMKN 1 Saptosari. Lokasi sekolah berada di Jl. Wonosari-Panggang, km.22, Kepek, Saptosari, Gunung Kidul.

\section{Subyek dan Karakteristiknya}

Subyek penelitian ini adalah siswa kelas XAV A Teknik Audio Video yang berjumlah 32 siswa yang diamati tingkah lakunya di saat pembelajaran berlangsung. Kelas XAV A terdiri dari 26 siswa laki-laki dan 6 siswa perempuan. Di kelas ini prestasi, latar belakang keluarga dan kemampuan belajar siswa sangat beragam. Sampel dipilih dengan menggunakan teknik purposive sampling yaitu teknik pengambilan sampel sumber data dengan pertimbangan tertentu. Sampel dalam penelitian ini berfungsi unuk mendapatkan informasi yang maksimum, bukan untuk digeneralisasikan (Sugiyono, 2007:301). Pertimbangan dalam penentuan samapel ini berdasarkan pada keberagaman nilai siswa dan kondisi kelas $\mathrm{X}$ AV A yang kurang dinamis dalam pembelajaran.

\section{Rencana Tindakan}

Penelitian ini merupakan penelitian tindakan kelas yang berupaya untuk mengubah kondisi sekarang ke arah kondisi yang diharapakan. Dalam penelitian ini peneliti sekaligus menjadi guru namun juga tetap melaksanakan pola kerja sama (kolaborasi) terutama dalam melaksanakan penelitian ( melaksanakan tindakan, observasi, merekam data, evaluasi dan refleksi). Untuk itu, peneliti berkolaborasi dengan guru serumpun.

Penelitian tindakan kelas ini menerapkan model spiral dari Kemmis dan Taggart yang dikemukakan oleh Mulyasa (2011:182) yang membagi prosedur penelitian tindakan dalam empat tahap kegiatan pada satu putaran (siklus) 
yaitu perencanaan, tindakan observasi dan refleksi dalam suatu spiral yang saling terkait. Tindakan dan keberhasilan pada siklus pertama harus diobservasi, dievaluasi dan kemudian direfleksi untuk merancang tindakan pada siklus kedua dan begitu seterusnya hingga diperoleh kemajuan yang diinginkan. Tahapan penelitian tindakan yang dilakukan adalah sebagai berikut:

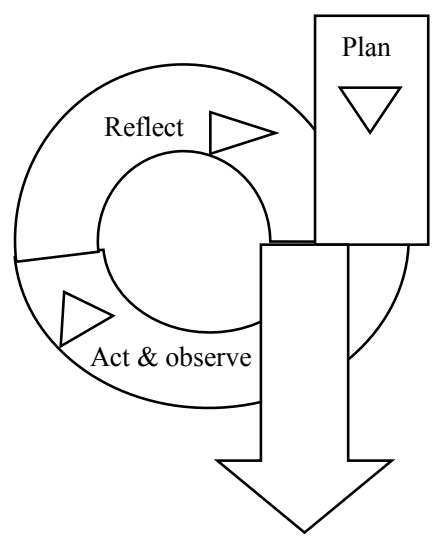

Gambar 1. Tahapan Kegiatan Penelitian Tindakan Kelas

\section{Tahap persiapan Penelitian Tindakan Kelas}

Pada tahap inipenelitimelakukan observasi tentang perilaku siswa terutama motivasi dan kemandirian siswa, dan mengamati hasil belajar siswa untuk menentukan kelompok-kelompok belajar. Observasi awal digunakan untuk mengetahui tingkat motivasi dan kemandirian siswa dalam pembelajaran dan sebagai acuan peningkatan yang terjadi setelah penggunaan STAD. Observasi ini juga dibutuhkan untuk menentukan langkah-langkah dalam pembelajaran kooperatif tipe STAD. Selain observasi kelas, dibutuhkan dokumentasi nilai siswa untuk acuan pembentukan kelompok belajar STAD. Langkah selanjutnya setelah observasi adalah menentukan rencana tindakan berupa tindakan siklus1.

\section{Siklus I}

Langkah pertama dalam siklus pertama ini adalah persiapan yang terdiri dari beberapa kegiatan yaitu: (1) membuat Rencana Pelaksanaan Pembelajaran (RPP) tentang materi teknik Audio sesuai dengan model pembelajaran yang akan digunakan, RPP disusun oleh peneliti dan dikonsultasikan dengan pakar/ahli terkait penelitian yang akan dilakukan, (2) mempersiapkan lembar observasi kelas, lembar ceklist motivasi siswa dan lembar ceklist kemandirian siswa, (3) membagi kelompok berdasarkan perbedaan prestasi, jenis kelamin, latar belakang budaya, dan (4) mempersiapkan soal tes untuk siswa, yaitu tes yang akan diberikan pada akhir pembelajaran dan akhir siklus. Tahap kedua yaitu pelaksanaan tindakan yang mengacu pada perencanaan yang telah dibuat dan pelaksanaannya bersifat fleksibel dan terbuka terhadap perubahan-perubahan. Selama proses pembelajaran berlangsung, guru mengajar sesuai dengan RPP yang telah dibuat dan disesuaikan dengan tujuan penelitian. Selama pembelajaran kolaborator mengamati interaksi guru dan siswa dalam lembar observasi kelas. Dalam pembelajaran yang menggunakan metode STAD kelas dibagi menjadi menjadi delapan kelompok dan setiap kelompok terdiri dari empat orang siswa. Pembagian kelompok mengacu pada prestasi dan jenis kelamin. Setiap kelompok terdiri dari siswa dengan prestasi tinggi, menengah dan rendah serta terdiri dari siswa laki-laki dan perempuan. Selama kegiatan diskusi kelompok guru (peneliti) dan kolaborator mengamati motivasi dan kemandirian siswa berdasarkan pada lembar observasi yang telah disusun. Tahap ketiga adalah observasi yang dilaksanakan selama dan sepanjang proses pembelajaran berlangsung dengan mengisi lembar observasi yang telah dibuat. Lembar observasi kelas bertujuan untuk mengetahui interaksi antara siswa dengan guru selama pembelajaran berlangsung. Sedangkan lembar observasi siswa berupa ceklist digunakan untuk melihat motivasi dan kemandirian siswa dalam pembelajaran. Tahap terakhir dalam siklus pertama ini adalah refleksi yaitu dengan mengolah data yang telah diperoleh dari observasi. Refleksi dilakukan bersama dengan peneliti kolaborator. Refleksi ini berupa diskusi antara peneliti dengan kolaborator dengan tujuan untuk mengevaluasi hasil tindakan yang telah dilakukan, yaitu dengan cara melakukan penilaian terhadap proses yang terjadi, masalah yang muncul, dan segala hal yang berkaitan dengan tindakan yang dilakukan. Dari hasil diskusi tersebut kemudian disimpulkan untuk 
mencari solusi terhadap kendala-kendala atau masalah yang mungkin timbul sehingga dapat dibuat rencana perbaikan pada siklus kedua.

\section{Siklus II}

Pada siklus kedua tahapan kegiatan yang dilakukan sama dengan siklus pertama yaitu persiapan, pelaksanaan, observasi dan refleksi. Tahap pertama adalah persiapan yang mengacu pada hasil refleksi yang telah dilakukan pada siklus pertama. Persiapan pada siklus II ini meliputi merevisi RPP, mempersiapkan lembar observasi, membuat kelompok baru dengan memperhatikan perbedaan prestasi (tinggi, sedang dan rendah) dan jenis kelamin dan mempersiapkan soal tes. Tahap kedua adalah pelaksanaan tindakan yang dilakukan sebagaimana pelaksanaan tindakan pada siklus pertama. Pembelajaran dilaksanakan mengacu pada RPP yang telah dibuat. Tahap ketiga adalah observasi yang dilaksanakan dengan mengamati siswa selama pembelajaran kemudian merekap hasilnya pada lembar observasi. Tahap terakahir adalah refleksi dimana dalam siklus kedua ini digunakan sebagai pembanding hasil dari siklus I. Dari siklus II ini diharapkan ada peningkatan motivasi, kemandirian dan hasil belajar siswa. Bila belum terjadi peningkatan yang signifikan maka siklus bisa diulang.

\section{Teknik dan Instrumen Pengumpulan Data}

Instrumen pengumpulan data dalam penelitian ini meliputi: (1) dokumentasi yang merupakan dokumentasi nilai siswa sebagai dasar pembagian kelompok STAD. Setelah kegiatan dalam kelompok berjalan, kemudian dilakukan tes tertulis untuk mengetahui siswa dengan nilai tertinggi dan terendah. Nilai siswa juga dijadikan sebagai penentu kelompok terbaik dalam kelas tersebut. Kelompok terbaik akan mendapatkan penghargaan dari guru. Hal ini dimaksudkan untuk memotivasi siswa agar belajar dengan baik; (2) Observasi yang meliputi lembar observasi kelas dan lembar observasi siswa. lembar observasi kelas digunakan untuk memantau interaksi guru-siswa sedangkan lembar observasi siswa digunakan untuk mengamati tingkah laku siswa selama proses pembelajaran berlangsung. Lembar observasi kelas diisi oleh kolaborator sebagai bukti bahwa peneliti benar-benar melakukan kegiatan penelitian dan mampu menjadi masukan untuk menentukan langkah-langkah dalam siklus selanjutnya; (3) Rencana Pelaksanaan Pembelajaran (RPP) yang digunakan sebagai panduan guru dalam melaksanakan pembelajaran di dalam kelas. Dalam penelitian ini RPP digunakan untuk memberikan perlakuan terhadap siswa yaitu dengan metode STAD.

\section{Teknik Analisis Data}

Analisis yang digunakan adalah analisis deskriptif yaitu sebuah analisis untuk menggambarkan data berdasar pada perhitungan mean, median, dan modus.

\section{Modus}

Modus merupakan nilai yang sering muncul dalam kelompok tersebut.

\section{Mean}

Mean merupakan nilai rata-rata atas kelompok tersebut. Rumus dari mean adalah sebagai berikut:

$$
\mathrm{Me}=\frac{\sum \mathrm{Xi}}{\mathrm{n}}
$$

\section{Median}

Median merupakan nilai tengah dari sekelompok data yang telah disusun urutannya dari yang terkecil hingga yang terbesar.

Sebelum melakukan pengujian terhadap instrumen maka perlu dilakukan uji validitas, reliabilitas instrumen dan uji beda.

\section{Uji Validitas Konstruk}

Pengujian validitas konstruk menggunakan analisis butir/item. Analisis butir (item) digunakan untuk mencari korelasi antara item dengan seluruh tes. Selain itu, analisis item ini juga digunakan untuk mengetahui korelasi antara peneliti dengan kolaborator. Analisis item menggunakan korelasi Product Moment dari Pearson dengan rumus:

$$
r_{x y}=\frac{\sum x y}{\sqrt{\left(x^{2}\right)\left(y^{2}\right)}}
$$


Keterangan:

$$
\begin{aligned}
& \mathrm{x}=\mathrm{X}-\mathrm{X}^{-} \\
& \mathrm{y}=\mathrm{Y}-\mathrm{Y}^{-} \\
& \mathrm{X}=\text { skor rata-rata dari } \mathrm{X} \\
& \mathrm{Y}=\text { skor rata-rata dari } \mathrm{Y}
\end{aligned}
$$

\section{Uji Validitas Isi}

Pengujian validitas isi adalah dengan membuat kisi-kisi instrumen berupa lembar observasi kelas dan check list. Selanjutnya kisi-kisi instrumen ini dikonsultasikan dengan para ahli (judment expert).

\section{Uji Reliabilitas Instrumen}

Pengujian reliabilitas instrumen dapat dilakukan dengan eksternal dan internal. Pengujian reliabilitas secara internal dapat dilakukan dengan internal consistency yaitu mencobakan instrumen sekali saja, kemudian data yang diperoleh dianalisis dengan teknik tertentu. Teknik analisis yang digunakan adalah Percentage of Agreement oleh Emmer\&Millet. Data dikatakan reliabel apabila koefisien reliabilitasnya $\geq 0,75$. Untuk menentukan koefisien reliabilitas digunakan rumus sebagai berikut:

$$
\begin{gathered}
\text { Percentage of Agreement }= \\
{\left[1-\frac{\mathrm{A}-\mathrm{B}}{\mathrm{A}+\mathrm{B}}\right] \times 100 \%}
\end{gathered}
$$

Keterangan:

A : skor pengamat yang skornya lebih tinggi

B : skor pengamat yang skornya lebih rendah

Selain menggunakan Percentage of Agreement, untuk mencari reliabilitas instrumen ini juga menggunakan Internal Consistency dengan rumus belah dua dari Spearman Brown. Adapun rumus tersebut adalah:

Keterangan:

$$
\mathrm{ri}=\frac{2 \mathrm{rb}}{1+\mathrm{rb}}
$$

ri $=$ reliabilitas internal seluruh instrumen

$\mathrm{rb}=$ korelasi product moment antara belahan pertama dan kedua.

Alasan pengunaan rumus ini karena dalam instrumen yang digunakan menggunakan skala
1 dan 0. Selain itu, jumlah butir dari kedua instrumen berjumlah genap.

\section{HASIL PENELITIAN DAN PEMBAHASAN}

\section{Hasil Uji Coba Instrumen}

Sebelum instrumen digunakan dalam pengumpulan data, maka terlebih dahulu dilakukan uji coba instrumen terhadap suatu sampel yang memiliki karakteristik sama dengan obyek penelitian. Uji coba instrumen dalam penelitian ini dilakukan di SMKN 1 Saptosari kelas X AV B. Alasan pemilihan sampel untuk uji coba karena X AV B adalah kelas yang melaksanakan pembelajaran Dasar Audio di semester genap sama dengan sampel yang akan diteliti yaitu kelas X AV A. Instrumen yang digunakan dalam penelitian ini adalah lembar observasi kelas, ceklist kemandirian siswa dan motivasi siswa. Lembar observasi diisi oleh kolaborator selama uji coba berlangsung dan selama penelitian berlangsung. Lembar observasi kelas digunakan setelah dikonsultasikan dengan pembimbing dan validator. Sedangkan ceklist diisi oleh peneliti dan kolaborator. Data hasil uji coba dianalisis untuk mengetahui validitas dan reliabilitasnya.

\section{Hasil Uji Coba Lembar Observasi Kelas}

Lembar observasi kelas merupakan instrumen untuk mengamati interaksi guru dengan murid. Selain itu, instrumen ini merupakan panduan bagi kolaborator selama mengamati penelitian tindakan kelas yang sedang berlangsung. Lembar observasi kelas juga digunakan untuk memastikan langkahlangkah pembelajaran kooperatif tipe STAD benar-benar dilakukan atau tidak. Hasil dari uji coba intrumen ini masih ada beberapa butir instrumen yang belum bisa dipenuhi oleh guru. Butir-butir tersebut adalah:

Butir pertama yang seharusnya siswa harus membawa artikel tapi dalam pelaksanaannya guru yang memberikan artikel kepada siswa untuk bahan diskusi. Tujuan dari penugasan artikel ini untuk mengetahui apakah siswa mampu menyediakan bahan belajar secara mandiri atau tidak, namun dalam pembelaajran 
yang terjadi adalah artikel disediakan oleh guru.

Tugas untuk siswa disampaikan secara lisan. Tujuan dalam penyampaian tugas secara lisan adalah supaya siswa memperhatikan apa yang disampaikan oleh guru sehingga bisa diketahui berapa besar fokus siswa pada materi yang sedang dipelajari. Namun hal ini dinilai kurang efektif karena dalam pembelajaran kooperatif, sentra belajar adalah siswa dan sebaiknya penugasan langsung disertakan dalam artikel sehingga tidak mengganggu konsentrasi siswa dalam mempelajari sebuah materi dari artikel.

Kolaborator tidak diberikan RPP yang merupakan panduan sebuah proses pembelajaran. Fungsi RPP dalam penelitian ini juga untuk panduan kolaborator mengamati proses pembelajaran yang berlangsung yang akan dituangkan dalam lembar observasi kelas.

Rencana pembelajaran belum tersosialisakan dengan jelas kepada siswa. Hal ini terlihat dari ketidaksiapan siswa ketika bekerja dalam kelompok sehingga menimbulkan kegaduhan di kelas.

Butir-butir diatas merupakan kekurangan yang diperoleh ketika melakukan observasi kelas. Kekurangan tersebut kemudian dibahas bersama kolaborator untuk menentukan langkah-langkah perbaikan.

Langkah perbaikan yang harus dilakukan adalah: (1) penugasan artikel kepada siswa harus diberikan pada pertemuan sebelumnya sehingga bisa diketahui siapa saja siswa yang tidak membawa artikel yang akan memudahkan untuk mengisi lembar ceklist kemandirian siswa, (2) penugasan kelompok berupa butir pertanyaan disampaikan secara tertulis di papan tulis. Hal ini untuk memudahkan siswa dalam proses diskusi. Lain halnya dengan pengukuran kemampuan individu siswa dengan tes, soal bisa diberikan secara lisan dengan batasan waktu atau dengan istilah dikte, (3) RPP harus diberikan kepada kolaborator sebagi panduan dalam mengamati interaksi guru dan siswa yang akan dilihat pada perjalanan waktunya (timing). Waktu dalam RPP dibandingkan dengan ceklist waktu dalam lembar observasi kelas dan akan dapat dilihat yang mendominasi pembelajaran. Apabila pembelajaran masih didominasi oleh guru maka STAD dikatakan tidak berjalan dan begitu sebaliknya bila pembelajaran waktu banyak digunakan siswa maka metode STAD dikatakan berjalan dengan baik, dan (4) rencana pembelajaran yang belum tersosialisasi dapat diatasi dengan memberitahukan kepada siswa kegiatan belajar yang akan dilaksanakan di awal pertemuan atau pertemuan minggu sebelumnya. Tujuan dari sosialisasi ini adalah untuk menyiapkan kondisi siswa secara materi maupun mental.

Hal yang dilakukan oleh peneliti dan kolaborator selanjutnya adalah menyusun RPP sebagai panduan dalam pengamatan proses pembelajaran dan panduan pengisian lembar observasi kelas. Peneliti terlebih dahulu mengajukan format RPP untuk Kompetensi Dasar "Attenuasi Gelombang" kemudian kolaborator melakukan tindakan koreksi terhadap format RPP tersebut. Lembar RPP disesuaikan dengan format yang ditentukan dengan memasukkan unsur pembelajaran kooperatif tipe STAD di dalamnya. Untuk melaksanakan pembelajaran kooperatif ini peneliti memperhatikan setiap langkah pembelajaran. Setelah format RPP disetujui maka RPP bisa digunakan dalam pembelajaran dan penelitian.

\section{Hasil Uji Coba Instrumen Motivasi Siswa}

Untuk mengetahui tingkat motivasi siswa sebagai data acuan penelitian, maka diperlukan sebuah pengamatan terbatas. Pengamatan terbatas ini dilakukan oleh dua orang yaitu peneliti bersama seorang kolaborator menggunakan lembar ceklist. Lembar ceklist ini berisi 12 butir pernyataan. Adapun prosedur pengisian lembar ceklist ini diberikan tanda $\sqrt{ }$ pada jawaban 'ya' dengan nilai 1 dan tanda pada jawaban 'tidak' dengan nilai 0 . Uji coba instrumen dilakukan oleh peneliti dan seorang kolaborator.

\section{Uji Validitas Isi}

Pengujian validitasisidengan caramembuat kisi-kisi instrumen kemudian dikonsultasikan dengan para ahli (expert judgment) yang ada dalam lingkungan prodi PTK. Hasil dari pengujian ini ada beberapa masukan antara lain dalam lembar observasi kelas, interval waktu pengamatan per 5 menit antar kegiatan. 
Tabel 1. Hasil Validitas Instrumen Motivasi Siswa

\begin{tabular}{clcc}
\hline No & Butir & Hasil & Keterangan \\
\hline 1. & Membawa artikel & Valid & Digunakan \\
2. & Membaca artikel & Tidak & Direvisi \\
3. & Menggabungkan materi artikel & Valid & Digunakan \\
4. & Serius mempelajari artikel & Valid & Digunakan \\
5. Tidak bercanda saat diskusi & Valid & Digunakan \\
6. & Berpendapat/ & Valid & Digunakan \\
7. & Fokus diskusi pada artikel & Valid & Digunakan \\
8. & Bertanya pada teman/guru pada hal yang belum dipahami & Tidak & Direvisi \\
9. Mampu membuat rangkuman dari artikel & Valid & Digunakan \\
10. Menuliskan hasil diskusi & Valid & Digunakan \\
11. Mempelajari rangkuman & Valid & Digunakan \\
12. Menyelesaikan tugas tepat waktu & Valid & Digunakan \\
\hline
\end{tabular}

Hal ini bertujuan memberikan kesempatan kepada kolaborator mengamati dengan benar proses pembelajaran yang dilakukan. Di dalam lembar observasi kelas kolaborator mengamati kegiatan pembelajaran, interaksi antara gurusiswa dan interaksi siswa dengan siswa dalam kelompok masing-masing. Lembar observasi yang digunakan untuk mengamati sikap siswa lebih baik menggunakan skala 1 dan 0 yang bertujuan memudahkan pengisian karena obyek pengamatan banyak.

\section{Uji Validitas Konstruk}

Uji validitas konstruk dalam instrumen ini adalah uji validitas item/butir terhadap skor total menggunakan teknik korelasi Product Moment dari Pearson. Butir instrumen yang dianalisis sebanyak 12 butir dengan obyek sebanyak 32 siswa, maka harga korelasi Product Moment $\geq 0,349$. Hasil perhitungan dihitung menggunakan SPSS 16 dan dikatakan valid apabila melebihi harga kritis sebesar 0,349. Adapun hasil dari perhitungan SPSS ada dalam tabel 1 .

Dari hasil pada tabel 1 butir instrumen yang tidak valid dan harus direvisi yaitu butir nomer 2 dan nomer 8 . Butir tersebut di atas tetap dipertahankan karena mempengaruhi instrumen yang akan digunakan.

\section{Uji Reliabilitas Instrumen Motivasi Siswa}

Uji reliabilitas dalam instrumen ini menggunakan Percentage of agreement yang dikemukakan oleh Ammer\&Millet. Perhitungan rumus ini menggunakan Microsoft Excel menghasilkan koefisien reliabilitas sebesar 0,94 yang berarti lembar ceklist ini reliabel dan bisa digunakan.

Untuk melihat kesamaan antara hasil uji coba instrumen oleh peneliti dan kolaborator, hasil uji coba instrumen instrumen ini juga dihitung menggunakan Indeks Kesesuaian Kasar (IKK). Data hasil uji coba instrumen dituangkan dalam tabel 2.

Tabel 2. Tabel Kesesuaian Hasil Pengamatan

\begin{tabular}{lcccc}
\hline & & \multicolumn{2}{c}{ Pengamat1 } & Jumlah \\
\cline { 3 - 4 } & & Ya & Tidak & Amatan \\
\hline Pengamat2 & Ya & 1, & 4,9 & 6 \\
& & 5, & & \\
& & 6, & & \\
& & 7 & & \\
& Tidak & 10, & 2,3, & 6 \\
& & 11 & 8,12 & \\
\hline Jumlah & 6 & 6 & 12 \\
\hline
\end{tabular}

Dari tabel 2 diketahui bahwa antara peneliti dengan kolaborator mempunyai penilaian yang sama terhadap obyek dalam butir nomor 1,2 , $3,5,6,7,8$ dan 12 . Adapun butir yang tidak sama adalah nomor 4, 9, 10 dan 11. Untuk itu perlu dihitung Indeks Kesesuaian Kasar dengan rumus:

$$
\begin{aligned}
& \mathrm{IKK}=\mathrm{n} / \mathrm{N} \\
& \mathrm{IKK}=8 / 12=0,66
\end{aligned}
$$




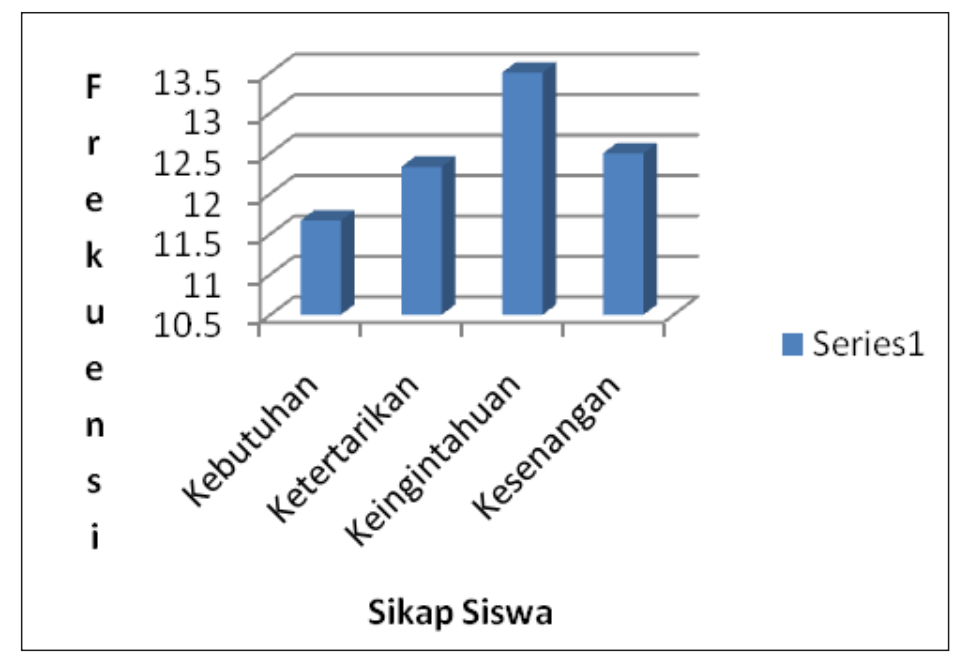

Gambar. 1. xxxxxxx

Tabel 3. Hasil Validitas Instrumen Kemandirian

\begin{tabular}{clc}
\hline No & Butir Instrumen & Hasil \\
\hline 1. & Mampu membuat keputusan & Valid \\
2. & Mampu berbagi tugas & Valid \\
3. & Melaksanakan tugas dengan baik & Valid \\
4. & Bekerja sesuai tugas dalam kelompok & Valid \\
5. & Menemukan ide untuk memecahkan masalah & Valid \\
6. & Tidak menyontek & Valid \\
7. & Tidak terlambat masuk kelas & Valid \\
8. & Serius dalam kegiatan pembelajaran & Valid \\
\hline
\end{tabular}

Maka hasilnya adalah 0,66 yang berarti terdapat kesamaan penilaian terhadap obyek dari peneliti dan kolaborator sehingga instrumen ini bisa digunakan. Data hasil pengamatan juga dihitung koefisien reliabilitasnya menggunakan Split-Half dari Spearman Brown. Dari perhitungan SPSS 16 diperoleh nilai hitung 0,632 yang berarti bahwa instrumen ini reliabel dan bisa digunakan.

\section{Uji Validitas Instrumen Kemandirian Siswa}

Untuk mengetahui tingkat kemandirian siswa ketika pembelajaran maka digunakan sebuah lembar ceklist sebagai instrumen pengamatan peneliti. Dalam uji cobanya, instrumen ini diisi oleh peneliti dan kolaborator. Lembar ceklist ini berisi tujuh butir pernyataan dengan prosedur pengisian jawaban 'ya; diberikan tanda $\sqrt{ }$ yang bernilai 1 sedangkan untuk jawaban 'tidak' diberikan tanda - yang bernilai 0 .
Seperti pada uji validitas instrumen motivasi siswa, uji validitas instrumen kemandirian juga menggunakan teknik korelasi Product Moment dari Pearson untuk mengetahui tingkat korelasi butir instrumen terhadap skor total. Analisis validitas menggunakan SPSS 16 terdapat dalam lampiran5 kemudian dituliskan ke dalam tabel 3.

Dari tabel 3 menunjukkan hasil bahwa semua butir instrumen valid dan bisa digunakan dalam penelitian.

\section{Uji reliabilitas}

Uji reliabilitas instrumen antara peneliti dengan kolaborator menggunakan metode percentage of agreement yang dikemukaakan oleh Ammer\&Millet. Perhitungan menggunakan Microsoft Exel. Hasil uji coba instrumen menunjukkan koefisien reliabilitas sebesar 0,96 yang berarti bahwa hasil pengamatan oleh dua orang tersebut reliabel. Analisis selanjutnya 
Tabel 4. Hasil Pengamatan Motivasi Siswa

\begin{tabular}{lllc}
\hline No & Komponen & Indikator & Skor \\
\hline 1 & Kebutuhan & Mampu memanfaatkan materi & 11,7 \\
& & Mampu bekerja sama & \\
2 & Ketertarikan & Semangat dalam kegiatan diskusi & 12,3 \\
& & Mampu menuangkan ide-idenya dalam kelompok & \\
3 & Keingintahuan & Memiliki rasa ingin tahu yang tinggi & 13,5 \\
4 & Kesenangan & Aktif dalam pembelajaran & 12,5 \\
\hline
\end{tabular}

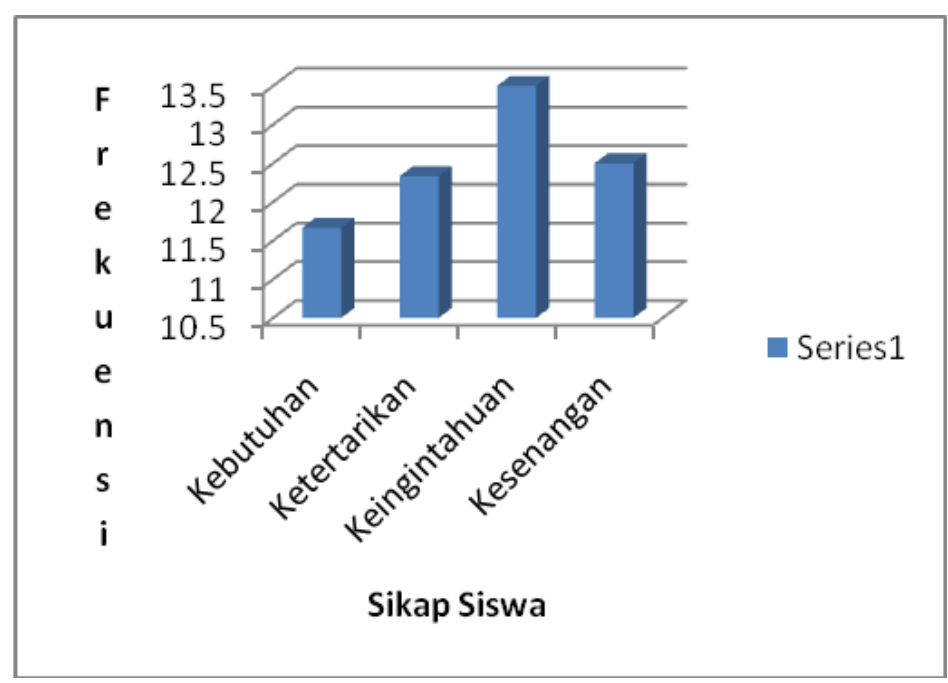

Gambar. 2. Grafik Motivasi Siswa SiklusI

adalah uji reliabilitas menggunakan rumus dari Spearman Brown yang menyatakan harga reliabilitas untuk 32 siswa $\geq 0,364$. Perhitungan menggunakan SPSS 16 menunjukkan koefisien reliabilitas sebesar 0,474 yang berarti instrumen ini reliabel dan dapat digunakan. Setelah instrumen dinyatakan valid dan reliabel maka instrumen ini digunakan dalam pengamatan sikap siswa.

\section{Siklus I}

Tahap-tahap Penelitian Tindakan Kelas di siklus I meliputi: (1) persiapan yang dilakukan dengan pembuatan RPP menggunakan format yang telah disetujui sekolah, (2) pelaksanaan dilakukan dalam pembelajaran Menguasai Dasar Teknik Audio yang dilakukan sesuai jadwal sekolah yaitu hari Jum,at menggunakan metode kooperatif tipe STAD maka terlebih dahulu membagi kelas menjadi beberapa kelompok kecil berdasarkan prestasi belajar, dan tiap kelompok harus memuat siswa lakilaki dan siswa perempuan, (3) observasi dimana dalam kegiatan ini, kolaborator mengamati aktifitas guru-siswa dan mengamati sikap siswa lalu menuliskan ke dalam lembar observasi kelas, (4) refleksi adalah tahapan dimana hasil penelitian dianalisis kemudian dilakukan tindakan koreksi terhadap kekurangan yang terjadi.

\section{Hasil Observasi Kelas}

Hasil dari observasi kelas adalah sebagai berikut: (1) terdapat kesuaian antara ploting waktu di RPP dengan lembar observasi kelas, (2) ada satu aktifitas yang tidak dilakukan guru yaitu tidak mencatat siswa yang tidak membawa artikel sehingga beluam ada reward dan punishment pada siswa supaya siswa lebih disiplin dalam pembelajaran, (3) presensi tidak harus satu persatu siswa karena sudah cukup mengenal siswa. 
Tabel 5. Hasil Pengamatan Kemandirian Siswa

\begin{tabular}{|c|c|c|c|}
\hline No & Komponen & Indikator & Skor \\
\hline \multirow[t]{3}{*}{1} & Bertanggung jawab & Mampu membuat keputusan & 13,5 \\
\hline & & Melakukan pembagian tugas kelompok & \\
\hline & & Mempunyai sikap tanggung jawab & \\
\hline \multirow[t]{2}{*}{2} & Tekun dan kreatif & Mampu mengembangkan ide & 13,5 \\
\hline & & Memanfaatkan waktu dengan baik & \\
\hline \multirow[t]{2}{*}{3} & Tidak mudah terpengaruh pada orang lain & Teguh pendirian & 12 \\
\hline & & Tepat waktu & \\
\hline \multicolumn{2}{|c|}{ Rerata } & & 13 \\
\hline
\end{tabular}

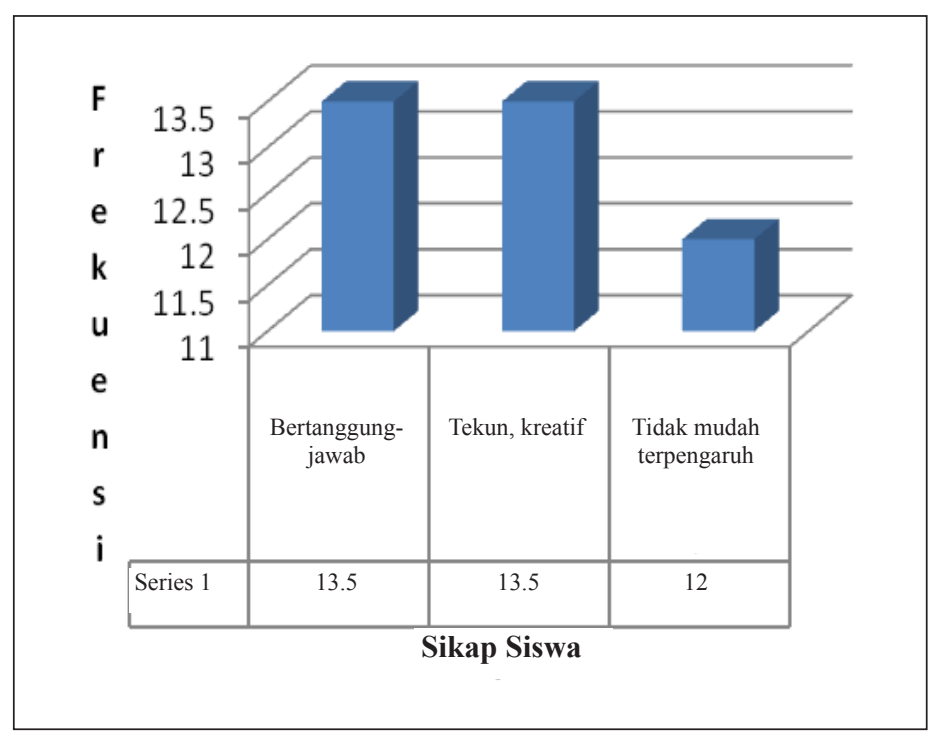

Gambar 3. Grafik Kemandirian Siswa Siklus I

\section{Hasil pengamatan motivasi siswa}

Pengamatan motivasi siswa dilakukan oleh kolaborator dengan cara memberikan tanda $\sqrt{ }$ pada instrumen motivasi siswa. Penggunaan lembar ceklist ini bertujuan supaya siswa secara alami dapat diketahui tingkat motivasinya melalui strategi pembelajaran tipe STAD. Hasil yang diharapkan adalah siswa menunjukkan motivasi yang lebih baik daripada sebelumnya. Hasil dari lembar pengamatan motivasi siswa dianalisis menggunakan analisis deskriptif yang bertujuan untuk menggambarkan tingkat motivasi siswa. Adapun hasil pengamatan motivasi siswa ada dalam tabel 4 .

Data pada tabel 4 dituangkan ke dalam grafik gambar 2. Dari hasil dapat diperoleh rerata siswa 12,5 .

\section{Hasil Pengamatan Kemandirian Siswa}

Pengamatan sikap kemandirian siswa yang dilakukan oleh kolaborator dapat dilihat pada tabel 5. Pada tabel 5 menunjukkan rerata skor ke-mandirian siswa sebesar 13. Yang berarti bahwa siswa yang menunjukkan tingkat kemandirian yang bagus sebanyak 13 anak.

Dari tabel di atas dapat digambarkan ke dalam grafik yang dapat dilihat pada gambar 3 .

Dari gambar 3 diperoleh rata-rata sebanyak 13 siswa yang mempunyai kemandirian. Oleh karena itu diperlukan sebuah perbaikan dari siklus I ini.

\section{Hasil Belajar}

Masing-masing kelompok kecil berusaha memperoleh skor kelompok untuk mendapat 


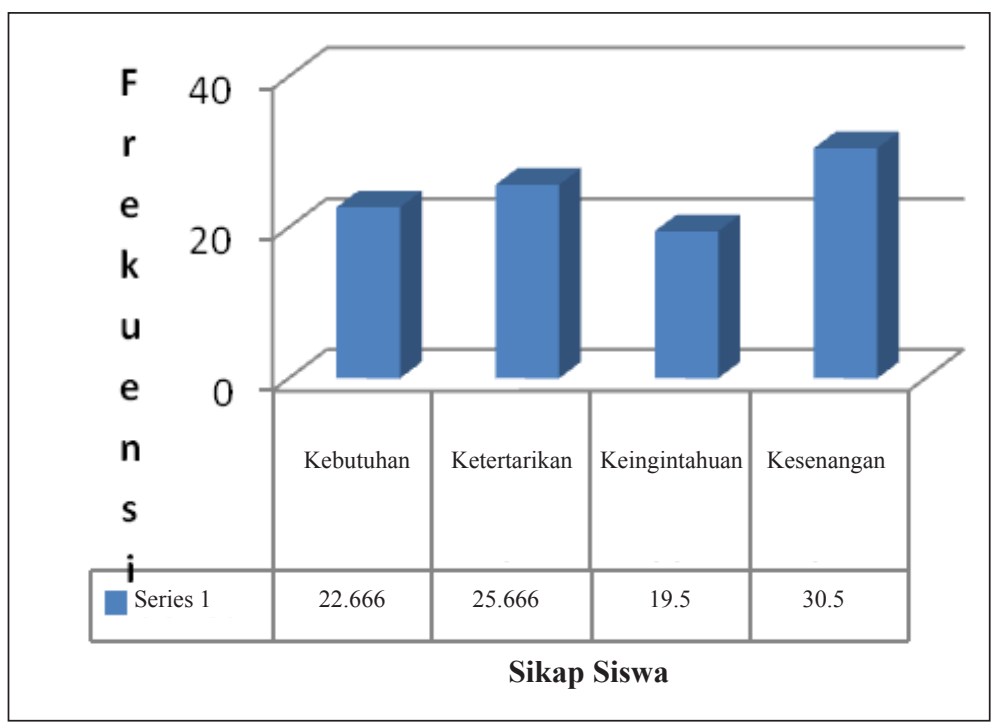

Gambar 4. Grafik Motivasi Siswa Siklus II

penghargaan sebagai tim terbaik. Skor kelompok diperoleh dari akumulasi skor anggota kelompok. Dari siklus pertama rerata hasil belajar siswa meningkat dan tidak ada siswa yang remidi karena tidak lulus KKM. Rerata nilai kelas di siklus pertama ini sebesar 8,16 dengan nilai tertinggi 9,0 dan nilai terendah 7,5. Siswa belajar lebih menyenangkan karena terjadi kompetisi antar siswa dan juga kompetisi antar kelompok. Dari pelaksanan siklus I masih ditemukan kekurangan yaitu: (1) pembelajaran dengan strategi STAD kurang berjalan efektif karena beban artikel. Dalam hal ini siswa diberi beban untuk mencari bahan belajar sendiri dengan tujuan agar siswa mandiri dalam menentukan bahan pelajaran yang sesuai dengan kurikulum yang sudah ditetapkan. Hasilnya, masih banyak siswa yang tidak mempedulikan hal ini. Oleh karena itu untuk mengatasi masalah ini diperlukan sebuah solusi. Adapun solusi yang dicapai ada dua opsi yaitu, (a) artikel diberikan oleh guru atau (b) siswa tetap diharuskan membawa artikel dengan syarat bila ada yang tidak membawa maka konsekuensi harus ditanggung oleh semua anggota kelompok. Akhirnya ditetapkan opsi yang kedua, karena opsi ini dianggap mampu meningkatkan tingkat kemandirian siswa yang harus bertanggung jawab atas tugasnya, (2) artikel yang dibawa siswa masih jauh dari materi yang diharapkan. Siswa yang sudah membawa artikel dengan tingkat kesesuaian materi yang bagus, perlu diberikan reward atau hadiah. Hal ini bertujuan supaya siswa benar-benar serius dalam mencari bahan pelajaran. Selain itu, guru juga wajib mengontrol ketercapaian siswa dalam mencari bahan ajar.

\section{Siklus II}

Di dalam siklus kedua ini tahapan yang dilalui sama seperti pada siklus pertama yaitu: (1) persiapan yang dilakukan dalam siklus II ini adalah menyiapkan RPP sesuai dengan format sekolah yang telah disetujui oleh Kepala Sekolah, (2) pelaksanaan dalam tahap ini, dimulai dengan pembagian kelompok berdasarkan pada hasil tes sebelumnya dan juga dalam satu kelompok harus ada siswa perempuannya, (3) observasi dengan mengamati jalannya pembelajaran di kelas, apakah sesuai RPP atau tidak dan hasil dari observasi kelas juga diperoleh hasil penelitian, dan (4) refleksi dengan cara melakukan perbandingan hasil di siklus pertama dengan hasil di siklus kedua.

\section{Hasil Pengamatan Motivasi Siswa}

Motivasi siswa yang diamati oleh kolaborator ditunjukkan dalam gambar 4 .

Dari grafik diatas diperoleh rata-rata skor motivasi sebanyak 24,5 atau sebanyak $77 \%$ siswa mempunyai motivasi melaksanakan pembelajaran di kelas. 


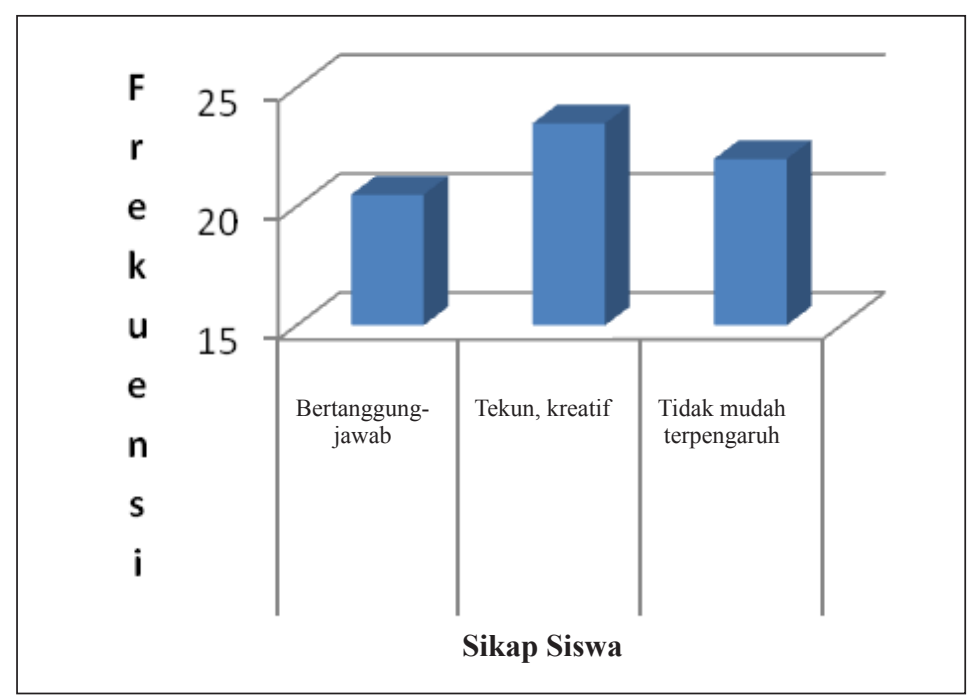

Gambar 5. Grafik Kemandirian Siswa Siklus II

\section{Hasil Pengamatan Kemandirian Siswa}

Hasil kemandirian siswa dapat dilihat pada gambar 5. Dari gambar 5 diperoleh data sebanyak $69 \%$ siswa menunjukkan kemandirian dalam pembelajaran dalam kelas. Siswa kurang bertanggung jawab atas pekerjaan yang harus diselesaikan dan masih menyontek saat ujian berlangsung. Sikap siswa yang harus diperbaiki untuk meningkatkan kemandirian siswa. Hasil observasi dari siklus kedua ini dapat dibandingkan dengan siklus pertama sehingga diperoleh data pencapaian motivasi siswa sebesar $76,6 \%$ yang berarti sudah memenuhi kriteria namun pencapaian kemandirian masih $69 \%$ dan belum mampu memenuhi kriteria. Karena keterbatasan waktu maka penelitian tindakan kelas ini dicukupkan sampai siklus II.

\section{Hasil Belajar Siswa}

Pada siklus kedua rerata nilai kelas adalah 8,66 dengan nilai tertinggi 10 dan nilai terendah 7,0. Semua siswa berhasil lulus KKM. Pencapaian ini merupakan hasil dari diskusi antar kelompok yang mengharuskan siswa memahami materi yang dipelajari. Ketika siswa benar-benar paham materinya maka untuk memenuhi standard KKM yaitu 7,0 mereka tidak akan kesulitan. Deskripsi hasil belajar Kompetensi Dasar Memahami Sifat Dasar Sinyal Audio dapat dilihat dari tabel berikut ini.

\section{Pembelajaran Kooperatif Tipe STAD mampu meningkatkan motivasi siswa}

Pada siklus I, diperoleh rerata skor 12,5 yang berarti pencapaian motivasi sebesar 39,06 $\%$. Sikap siswa yang paling rendah adalah memiliki rasa butuh atas materi yang dipelajari. Hal ini disebabkan rendahnya kemampuan siswa dalam melaksanakan tugas merangkum materi yang telah diperoleh dan kurangnya siswa yang menuliskan hasil diskusi kelompok ke dalam buku tulis masing-masing. Padahal kegiatan ini merupakan kebutuhan siswa sebagai upaya untuk memahami materi yang dipelajari. Artinya, siklus I penelitian ini baru memotivasi siswa sebanyak 39,06\%. Di siklus kedua pencapaian skor motivasi sebesar 24,6 yang berarti siklus II mampu meningkatkan motivasi siswa sebanyak $76,6 \%$ dari populasi yang diteliti.

Perbandingan pencapaian indikator sikap siswa terdapat dalam tabel 6 .

\section{Pembelajaran kooperatif tipe STAD mampu meningkatkan kemandirian siswa}

Siklus I penelitian diperoleh data tingkat kemandirian siswa dengan skor 13 . Hal ini berarti bahwa sebanyak $43 \%$ siswa mempunyai tingkat kemandirian yang bagus. Variabel tidak mudah menyerah adalah variabel dengan skor pencapaian paling rendah. Dari variable ini butir terendah terletak pada butir 
Tabel 6. Skor Peningkatan Motivasi Siklus1 \& Siklus 2

\begin{tabular}{llccc}
\hline \multirow{2}{*}{ No. } & \multirow{2}{*}{ Indikator } & \multicolumn{2}{c}{ Skor Pencapaian } & \multirow{2}{*}{ Peningkatan (\%) } \\
\cline { 3 - 4 } & & Siklus $\mathbf{1}$ & Siklus 2 & \\
\hline 1. & Kebutuhan & 11,7 & 22,6 & 10,9 \\
2. & Ketertarikan & 12,3 & 25,6 & 13.6 \\
3. & Keingin tahuan & 13,5 & 19,5 & 3 \\
4. & Kesenangan & 12,5 & 30,5 & 18 \\
\hline
\end{tabular}

Tabel 7. Skor Pencapaian Kemandirian Siklus $1 \& 2$

\begin{tabular}{llccc}
\hline \multirow{2}{*}{ No } & \multirow{2}{*}{ Indikator } & \multicolumn{2}{c}{ Skor Pencapaian } & \multirow{2}{*}{ Peningkatan (\%) } \\
& & S 1 & S 2 & 7 \\
\hline 1. & Bertanggung jawab & 13,5 & 20,5 & 10 \\
2. & Tekun dan kreatif & 13,5 & 23.5 & 10 \\
3. & Tidak mudah terpengaruh & 12 & 22 & \\
\hline
\end{tabular}

Ket: $\mathrm{S} 1=$ siklus I

$\mathrm{S} 2=$ siklus II

6 yaitu teguh pendirian. Artinya tes yang dilaksanakan banyak siswa yang nyontek temannya. Sedangkan butir yang paling tinggi skornya adalah butir kedua dan kesepuluh yang berarti bahwa siswa yang menjadi ketua kelom;pok mampu membagi tugas dalam kelompoknya masing-masing dan mampu menyelesaikan pekerjaan tepat pada waktunya. Siklus II pencapaian skor kemandirian siswa sebesar 22 yang berarti bahwa sekitar 69\% siswa yang mempunyai tingkat kemandirian bagus. Sedangkan pencapaian masing-masing indikator dalam kemandirian siswa terdapat dalam tabel 7.

\section{Pembelajaran kooperatif tipe STAD mampu meningkatkan hasil belajar siswa}

Hasil belajar siswa sebelum STAD diberlakukan mencapai rerata 6,66 dan masih banyak siswa yang belum memenuhi KKM. Setalah STAD diberlakukan pada siklus pertama rerata nilai kelas 8,16 dan pada siklus kedua rerata nilai 8,66 . Pada pembelajaran kooperatif ini semua siswa mampu memenuhi KKM sehingga guru tidak perlu melakukan remidial. Adapun peningkatan nilai hasil belajar siswa terdapat dalam tabel 8 .

Rerata nilai siswa di akhir siklus kedua meningkat 0,5 dari siklus pertama. Namun di siklus kedua nilai terendah tidak lebih baik dibanding siklus pertama walaupun masih memenuhi KKM.

Tabel 8. Data Hasil Belajar Siswa

\begin{tabular}{ccc}
\hline Sumber Statistik & Siklus1 & Siklus2 \\
\hline N & 32 & 32 \\
X & 8,16 & 8,66 \\
S & 0,53 & 0,95 \\
Min & 7,5 & 7,0 \\
Max & 9,0 & 10 \\
\hline
\end{tabular}

\section{Perolehan Pengetahuan Peneliti}

Dari penelitian ini diperoleh beberapa pengetahuan yaitu pembelajaran kooperatif tipe STAD mampu meningkatkan motivasi belajar, kemandirian dan hasil belajar siswa pada Standard Kompetensi Menerapkan Dasar Sinyal Audio. Strategi pembelajaran ini diterapkan pada proses pembelajaran teori yang memperhatikan aspek kognitif dan afektif.

\section{Keterbatasan Penelitian}

Dalam penelitian ini terdapat beberapa keterbatasan antara lain: (1) Penelitian tindakan kelas yang dilakukan adalah penelitian yang terbatas pada kelas dan mata pelajaran tertentu, (2) dalam pelaksanaan pembelajaran 
kooperatif tipe STAD dilaksanakan sebanyak dua pertemuan setiap siklusnya. Padahal seharusnya dalam satu siklus terjadi 3-5 pertemuan. Hal ini dilakukan karena waktu yang terbatas dalam penelitian ini, (4) hasil penelitian mampu meningkatkan motivasi siswa namun tingkat kemandirian belum sesuai yang diharapkan, (5) materi pembelajaran terbatas pada teori bukan materi praktek, jadi perlu adanya penerapan pada materi praktek dan (6) peningkatan motivasi, kemandirian dan hasil belajar siswa tidak hanya bisa dilakukan dengan STAD namun juga dengan strategi yang lainnya.

\section{SIMPULAN DAN SARAN}

\section{Simpulan}

Berdasarkan data dan pembahasan yang diperoleh, maka dalam penelitian ini dapat disimpulkan sebagai berikut: (1) pembelajaran kooperatif tipe STAD dapat meningkatkan motivasi belajar siswa. Tingkat kebutuhan siswa terhadap materi menunjukkan kenaikan yang berarti dari siklus pertama ke siklus kedua, (2) pembelajaran kooperatif tipe STAD juga dapat meningkatkan kemandirian siswa dalam belajar. Hasil penelitian menunjukkan bahwa sikap siswa yang dominan dalam meningkatkan kemandirian siswa adalah tekun, kreatif dan tidak mudah terpengaruh orang lain. Hal ini yang membuktikan bahwa STAD mampu membuat siswa mandiri tidak tergantung orang lain, (3) pembelajaran kooperatif tipe STAD mampu meningkatkan hasil belajar siswa. Sebelum penggunaan STAD banyak siswa yang tidak memenuhi KKM, namun pada siklus pertama pembelajaran dengan menerapkan strategi kooperatif semua nilai siswa mampu mencapai KKM. Hal ini karena pembelajaran yang lebih menarik, materi dipelajari bersamasama, siswa pintar membimbing siswa yang kemampuannya di bawahnya.

\section{Implikasi}

Implikasi dari penelitian ini adalah : (1) paradigma sistem pembelajaran dari teacher centre menjadi students centre mendorong guru membuat suatu pembelajaran menjadi menyenangkan. Salah satu strategi yang dapat dipilih yaitu pendekatan kooperatif yang mampu membuat siswa aktif di kelas sehingga pembelajaran lebih menyenangkan, (2) dari penelitian ini dibuktikan bahwa pembelajaran kooperatif mampu meningkatkan motivasi, kemandirian dan hasil belajar siswa. Dengan adanya strategi pembelajaran kooperatif maka suasana kelas yang awalnya didominasi guru berubah menjadi suasana kelas yang mengaktifkan siswa dengan diskusi dan kuis yang menarik, sehingga mampu mendorong siswa mempelajari materi dengan lebih mendalam.

\section{Saran}

Berdasarkan simpulan dan implikasi diatas berikut ada beberapa saran untuk peningkatan motivasi, kemandirian dan hasil belajar siswa menggunakan pembelajaran kooperatif tipe STAD antara lain:

\section{Sekolah}

Sekolah diharapkan memberikan kesempatan kepada para guru untuk mengembangkan diri ke luar maupun ke dalam. Pengembangan diri ke luar artinya sekolah memberikan kesempatan kepada guru untuk mengembangkan potensinya dengan cara mengikuti seminar atau diklat yang dilaksanakan untuk meningkatkan kualitisa pembelajaran. Pengembangan diri kedalam dimaksudkan guru bisa melakukan penelitian di sekolah untuk meningkatkan kualitas siswa.

\section{Guru}

Guru diharapkan mampu mengidentifikasi permasalahan yang terjadi di kelas terutama dalam pembelajaran sehingga masalah tersebut dapat diatasi. Sebagai pendidik, guru diharapkan mampu mengembangkan kemampuan mengajar terutama dalam hal penggunaan strategi pembelajaran. Permasalahan yang terjadi di kelas bisa diatasi dengan pendekatan belajar siswa aktif berupa diskusi kelompok dan kompetisi sehat siswa dalam penguasaan materi tertentu.

\section{Peneliti}

Bagi peneliti lain yang membaca penelitian ini dan ingin mengembangkannya maka hendaklah benar-benar diperhitungkan waktu pelaksanaannya karena pembelajaran STAD 
memerlukan waktu lama untuk mencapai hasil terbaik. Selain itu, bisa dilakukan dalam skala yang lebih besar dan pembelajaran teori beserta prakteknya.

\section{DAFTAR PUSTAKA}

Ali, M. \& Asrori, M.(2008). Psikologi remaja : perkembangan peserta didik. Jakarta : PT.Bumi Aksara

Borich, G.D. (2007). Effective teaching methods. Ohio: Pearson Prentice Hall

Capel, S., Leaks, M. \& Turner, T. (1997). Learning to teach in the secondary school. London: Routledge

Chance, P,L. (2009). Introduction to educational leadership \& organizational behavior. New York: Eye On Education

Djaali. (2008). Psikologi pendidikan. Jakarta: Bumi Aksara

Djojonegoro, Wardiman. (1998). Pengembangan sumber daya manusia melalui SMK. Jakarta: Jaya Agung Offset

Hamalik, O. (2002). Psikologi belajar mengajar. Bandung: Sinar Baru Algesindo Hamzah, B.U. (2011). Teori motivasi dan pengukurannya. Jakarta : Bumi Aksara

Joyce, B. \& Weil, M. (1996). Models of teaching. United States of America: A Simon \& Schuster Company

Kidd,W., \& Czerniawski, G. (2010). Successful teaching : theori, practice and reflection. London : SAGE Publications Ltd

Killen,R. (2009). Effective teaching strategies: lesson from research and practice. Victoria: Cengage Learning Australia

Klein, B.S. (2010). Learning. Misissippi : McGraw Hill

Marsh, C. (1996). Handbook for beginning teachers. Sydney: Addition Wesley Longman Pty limited.
McLean, A. (2009) . Motivation every learner: London : SAGE

M. Dell 'Olio, J. \& Donk, T. (2007). Models of teaching : connecting students learning with standard. London : Sage Publications Ltd

Monks.(1994). Psikologi perkembangan: pengantar dalam berbagai bagian. Yogyakarta: Gadjah Mada University Press

Reid, G. (2009). Memotivasi siswa di kelas: gagasan dan strategi. London: Paul Champman Publishing. Terjemahan Hartati Widiastuti. (Buku asli diterbitkan tahun 2007)

Ringer, R. (1990). The 19 habits of highly successful people: powefull strategies for personal triumph. Kuala Lumpur: Wyn Wood Press

Roger, T \& David, W.J (2009). An Overview of Cooperative Learning. Diambil pada tanggal 20 Agustus 2012 dari http://www.co-operation.org/pages/ overviewpaper.html

Sanjaya, W. (2007). Strategi pembelajaran berorientasi standard proses pendidikan. Jakarta: Kencana Prenada Media

Schunk, H. D., et.al, (2010). Motivation in education. London: Pearson

Setiadi, R. (22 April 2012). Mengenal pendidikan berkarakter. diambil dari http:// edukasi.kompasiana.com/ 2012/04/22/ mengenal-pendidikan-berkarakter/ dowlnoad pada tanggal 5 Agustus 2012

Skiba, R. \& Peterson, R. Cooperative Learning. Diambil pada tanggal 28 November 2012 dari www.indiana.edu/ $/$ safeschl Strommen, E. (1995). Cooperative Learning. Journal of Electronic Learning, 14, 24-35.

Slavin, E. Robert. (1998). Cooperative Learning(Theory, Research and Practice). London: Allyn and Beacon 
(2005). Coopertive Learning. (terjemahan Nerulita Yusron). London: Allyn and Bacon

Suprijono, Agus. (2010). Cooperative learning, teori dan aplikasi PAIKEM..Yogyakarta: Pustaka Pelajar
Uno, Hamzah B. (2011). Teori motivasi dan pengukurannya. Jakarta : Bumi Aksara 